\title{
Developing Economic Values in Football: Example of Turkish Football Federation
}

\author{
Serdar Terekli, Halil Orbay Çobanoğlu \\ Anatolia University, Eskişehir, Turkey \\ Email: msterekli@anadolu.edu.tr
}

How to cite this paper: Terekli, S. and Çobanoğlu, H.O. (2018) Developing Economic Values in Football: Example of Turkish Football Federation. Open Access Library Journal, 5: e4263.

https://doi.org/10.4236/oalib.1104263

Received: December 16, 2017

Accepted: February 24, 2018

Published: February 27, 2018

Copyright $\odot 2018$ by authors and Open Access Library Inc.

This work is licensed under the Creative Commons Attribution International License (CC BY 4.0).

http://creativecommons.org/licenses/by/4.0/

(c) (i) Open Access

\begin{abstract}
Economics is a science that examines how people use scarce and limited sources of production to produce various commodities and distributes them to various members of society for consumption. Increasing economic value has introduced a new task for the football federation and has become an important financial resource of sports clubs. When it is considered as football industry, football organizations, football business, football media, football products, soccer technology, soccer marketing and soccer federation are seen in the production and consumption of goods and services in the football. Indirect management of economic benefit through sports is a direct link to clubs and federations. The economic entrepreneurship that stands out in the professional football gives the football a great popularity and enables the income to be obtained more easily. Today, the football market has reached a budget expressed in billion dollars. For this reason both sports clubs and federations have to plan their budgets according to the rules of the economy. The aim of this study is to provide important economic resources in the football club and the football economy having a major impact to analyze the financial performance of the Turkey Football Federation and to examine the contribution made to improve the financial condition of the football club.
\end{abstract}

\section{Subject Areas}

Development Economics

\section{Keywords}

Football Clubs, Financial Analysis, Professional Football, Premier League Football, Football Federation

\section{Introduction}

Sports is an activity that has many reflections in economic terms. Sports has 
shown great economic, social and political developments over the last century and has become one of the most important economic instruments that provide great benefits to the country's economy. Many companies that are not interested in sports in their activities start to deal with the sports economy expressed in the market of million dollars and make big investments.

Nowadays, football has begun to take first place among the most important sectors, which are expressed by big numbers both economically and commercially. Football is a global phenomenon born in Europe and still dominated by European clubs both as sporting success and economically. This development led to the growth of financial value economically, both the growth of funds and the introduction of public offerings have made increasingly important the existence of a transparent and sound financial structure at the level of the clubs and federations in the football. For this reason, both sports clubs and federations have had to plan their budgets according to the rules of the economy. Because it is a subdivision of the sports sciences that produce inputs and outputs based on specific plans and projects that make radical decisions based on football economics experiences expressed in millions of dollars.

In the football economy, clubs, footballers, fans are only a part of this work. Besides, the income from the variables such as ticket and product sales, sponsors, live broadcasts, and betting shows that football is a professional profession. However, it should not be forgotten that performance in football is related to economic success.

Over the past half century, the American Football League (NLF) has been seen to be three times as valuable as the Premier League, the nearest football league to itself. NLF's publishing rights are much more expensive, despite the fact that NLF league has 100 million and football has 4 billion. Despite Real Madrid's 18 million followers, Dallas Cowboys is the world's most valuable team, with only 1.5 million followers, and the closest follower is worth more than $\$ 750$ million from Madrid [1].

What is important here is to manage the current economic structure in the healthiest way. In recent years, the European Football Association (UEFA), the regulatory authority of the European Football Federation (UEFA), has imposed certain sanctions on soccer clubs, particularly those involving the financial position and measured by the compliance grade financial performance criteria. The most important of these sanctions is the financial fair play criteria. It is aimed to strengthen the financial structure, sustainability and balanced competition in the federations with the financial fair play criteria. With the equivalent budget application, which is the basis of the financial fair play criteria required for participation of the clubs in UEFA organizations, a financial structure is monitored in the clubs and it is aimed to reach the break-even point of the clubs that have completed the transition process [2]. Taking the right decisions in the football industry is very important in terms of being a serious competition in this industry. 


\section{Environmental Factors Affecting Football Economy}

The fact that professional soccer is a game that is linked to many things beyond the game has made football a professional business area that different segments are interested in. The clubs have offered football supply to the market and the commercialization federations have become a gigantic economic structure where the buyers, audiences, supporters and stadiums to buy the product are transformed into trading complexes, and the products of the clubs are sold and new communication possibilities are used.

The football economy has an asymmetric, inelastic and irrational structure. Although football has become an industry, it is a business that carries its own differences in a way that is far different from other industries. This industry rises on the basis of supporter affiliation and finds life [3].

Figure 1 shows the micro dimension of the football economy as a business line. Soccer is a popular sport when viewed socially. Strong clubs, preferences and decisions are treated as rational fans and national teams. In fact, it can be said that sports way of football is only a part of the football clubs and federations. For this reason, the idea of a business line of the football industry is always missing. Each of the micro environments of the business environment in football is only football-specific.

For this reason, football economics is theoretically determined that is a sector with originality, classical economic rules do not work in this economy by both supply and demand, there is an asymmetric structure in the price formation, the price of goods or services sold is not determined very rationally as classical economics and this economy has a solidarity in the economy, the opponents could not destroy each other [3].

Besides all the companies working in the football business, one of the most important factors influencing the presence of the football club, the federations and the league is the players. In this section, the fans may come to mind. In the football economy, fans do not give up their teams even if they perform badly,

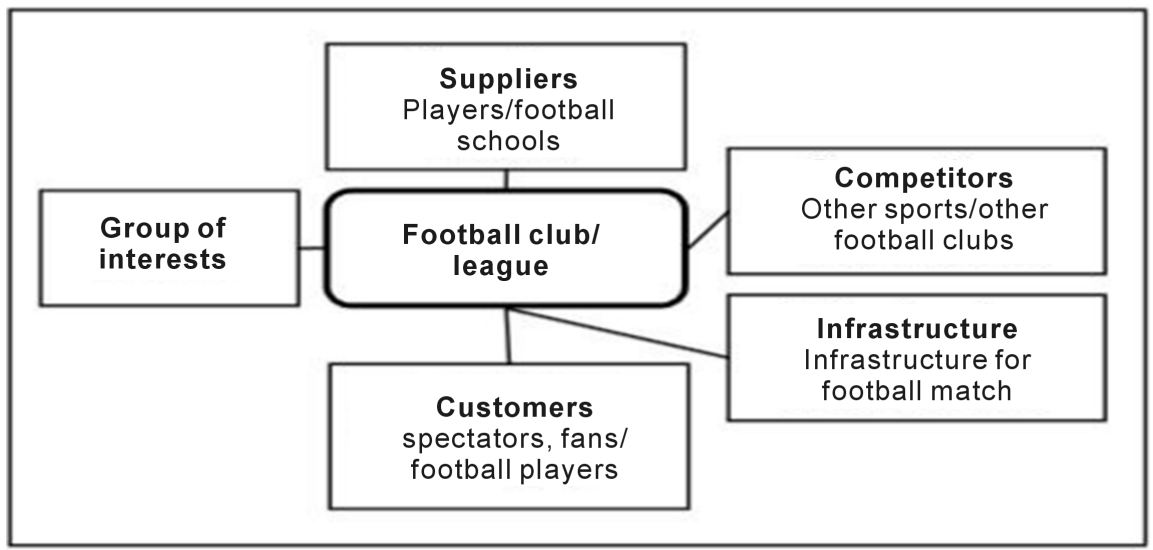

Figure 1. Micro-environment elements of football business. Source: Karpavicius and Jucevicius (2009), "The application of the business system concept to the analysis of football business", Inzinerine Ekonomika-Engineering Economics, p. 87. 
and when poor performance brings financial problems they increase their spending and support their teams. Football players who became a sponsor for the football club are also the customers of the football industry [4]. For this reason, players have an important influence on the rise and fall of brand value of clubs, federations and leagues. This effect broadens or narrows the monetary holdings of clubs, federations and leagues.

However, in our country, there is great difficulty in the administrative structure of football and all the institutional substructures formed there from. The total debt of our clubs, called the four major clubs, has exceeded the $\$ 6.5$ billion [5]. Nevertheless, the volume of football in the professional soccer market in Turkey has grown about 5 times in the last 10 years. At least in the growth of monetary overpayment, it can be shown that fans do not leave their teams, change in sponsorship mentality, increase in broadcasting income and increase in interest in betting game every passing day.

Figure 2 shows the income stream in the soccer economy. Some of them are press, globalization, trade, corporations, capital, spectators (fans) and players. However, the three most rewarding sources of incomes for football clubs are:

- Transmission Incomes

- Commercial Incomes

- Match Day Incomes

In the football which has been transformed into a global show industry in the last 25 years, match day revenues comes from the income items which sports fans directly influence. The match-day revenues of the clubs, which provide clues to their sporty successes and popularity, consist of ticket and combined sales as well as revenues from institutional hospitality and food and beverage

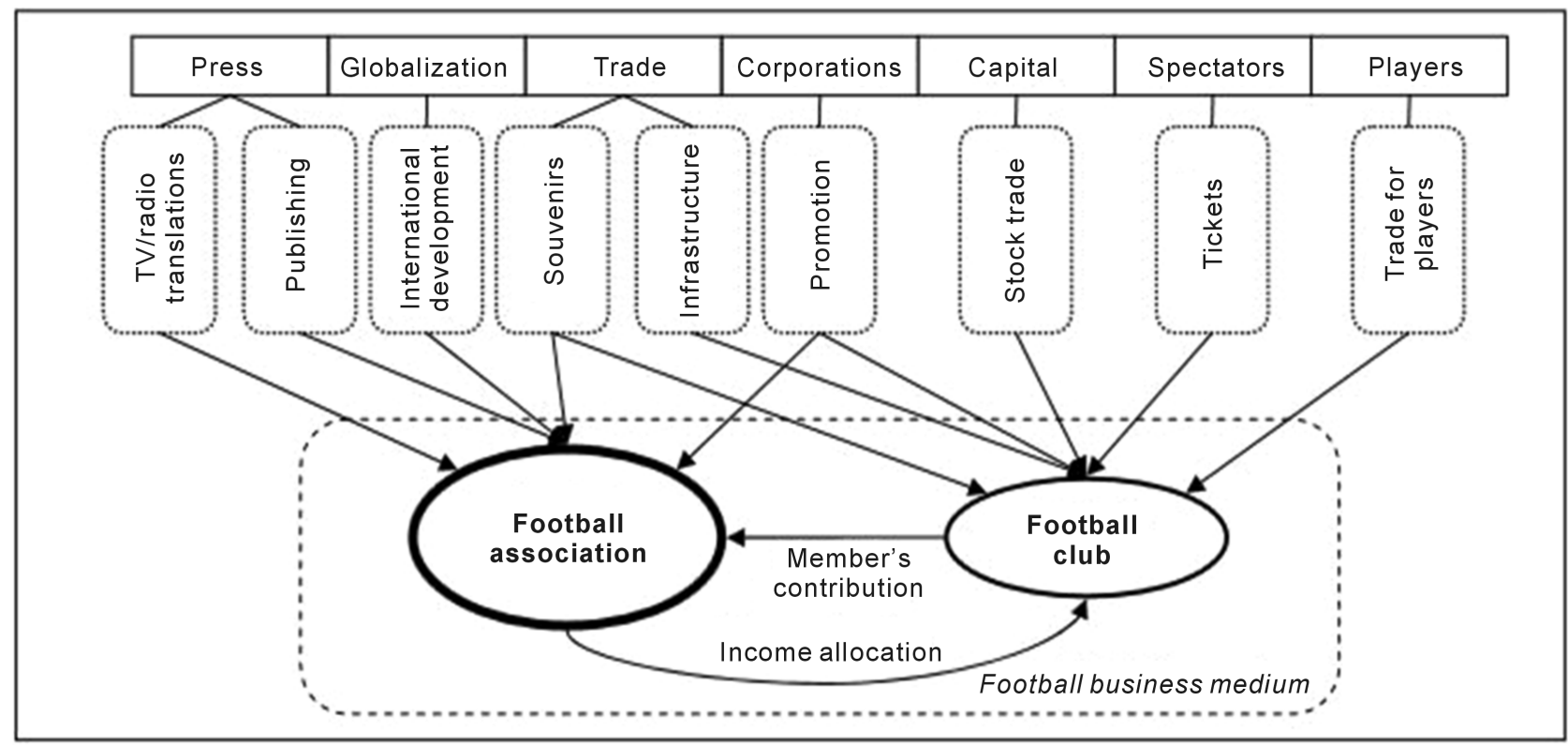

Figure 2. Income flows of football business system. Source: Karpavicius \& Jucevicius (2009), "The application of the business system concept to the analysis of football business", Inzinerine Ekonomika-Engineering Economics, p. 90. 
services. These incomes also reflect the behavioral identities of the football culture and supporters of that country or region.

Compared to Europe's 5 major leagues, the Premier League is ranked first in terms of match day income. Apart from sales of seasonal combos and match tickets, catering services offered at different stadiums according to different customer segments and institutional entertainment packages should not forget effects of this revenue. The modern stadiums of Premier League especially Emirates, Stamford Bridge, Old Trafford and Etihad Stadium, compete with each other with alternative accommodation services, VIP lounge areas, private venues and catering services offered outside the match days or match days [6].

The globalization of sports and the transformation into consumption culture began with television. Thanks to sporting activities, the incomes of television channels, which have been watched for a longer period of time, have increased significantly. Parallel to these developments, football has become an instrument that can be marketed in every direction as well as being presented to sports fans in the form of a spectacular activity. France, which has been hosting EURO 2016 in the past few months, is one of the most striking examples of this pioneering change in Europe.

At the end of 1960s, the first year of television, the sports broadcasts, which were 232 hours per year in France, reached 430,000 times in 2010, up to 100,000 hours. The situation is the same as the cradle of modern football in England. Between 1993 and 1998, the time that British television channels dedicated to sports broadcasts increased by $300 \%$. In the second half of the 1980s, sports broadcasts began to meet television audiences through paid channels instead of open channels that everyone could watch. This development changed the face of the football-television partnership. With this trend that started at the forefront of the European continent, popular sporting events began to be offered to sports fans through encrypted private TVs and for certain fees. As the number of companies that advertise in sports publications has increased, soccer has turned into one of the most expensive global shows that have been marketed to millions of people. Nowadays, soccer competitions of each country are delivered to television audience with different broadcasting and distribution models [6].

These models vary according to many factors such as the socio-economic dynamics of the existing countries, the popularity of the league, sporting success and brand value, international travel demand, advertising and subscriber revenues, broadcasting technology. Live revenue in England is distributed to the Premier League clubs by the rule of 50-25-25. In this model, the Federation initially equates $50 \%$ of total revenues to all clubs. Then half of the remaining $50 \%$ is distributed according to sportive performance, and the other half is distributed according to the weekly broadcast game numbers, depending on the popularity of the clubs.

In Turkey, revenues from live broadcasts are allocated to the Spor Toto Super League teams as follows. $35 \%$ of total publishing revenue is distributed equally to 
18 clubs as contribution share. $45 \%$ of the remaining revenues are awarded to performance (score points), $11 \%$ to the championship numbers and $9 \%$ to the first six teams (Figure 3).

Since 1990, football has entered the process of industrial transformation. Commercial income is one of the income items that have increased significantly in the last 10 years. Along with the changing socio-economic conditions and new stakeholders involved in football, the commercial revenues of the clubs have also diversified and increased. Digital platforms are one of the newest areas of commercial revenues in recent years, including sponsorship agreements, brand partnerships, commercial associations, advertising, image and PR projects. The sum of commercial revenues in the 2014-2015 football season of Europe's five largest leagues is set at 3.4 billion Euros. The UK is ranked first with 1.2 billion Euros, followed by Germany with 673 Euros.

In Turkish football, the four big are the ones with the highest commercial incomes. However, in recent years it is seen that some clubs with the stadiums renewed, the performances in the league and the potentials of the audience Antalyaspor, Atiker Konyaspor, Medipol Başakşehir FC have also increased their commercial income. In the 2014-2015 football season, four (Çaykur Rizespor, Kardemir Karabükspor, Medipol Başakşehir FC, Atiker Konyaspor) of the 18 football clubs in the Sports Toto Super League were title sponsors, and three (Türk Telekom Arena, Vodafone Arena, Torku Arena) of them were stadium name sponsors.

Also in the 2015-2016 football season, four (Çaykur Rizespor, Medicana Sivasspor, Medipol Başakşehir FC, Atiker Konyaspor) of the 18 football clubs were title sponsors, five (Türk Telekom Arena, Vodafone Arena, Ülker Stadium Fenerbahçe Şükrü Saraçoğlu Sports Complex, Torku Arena, Didi Stadium) of them were stadium name sponsors.

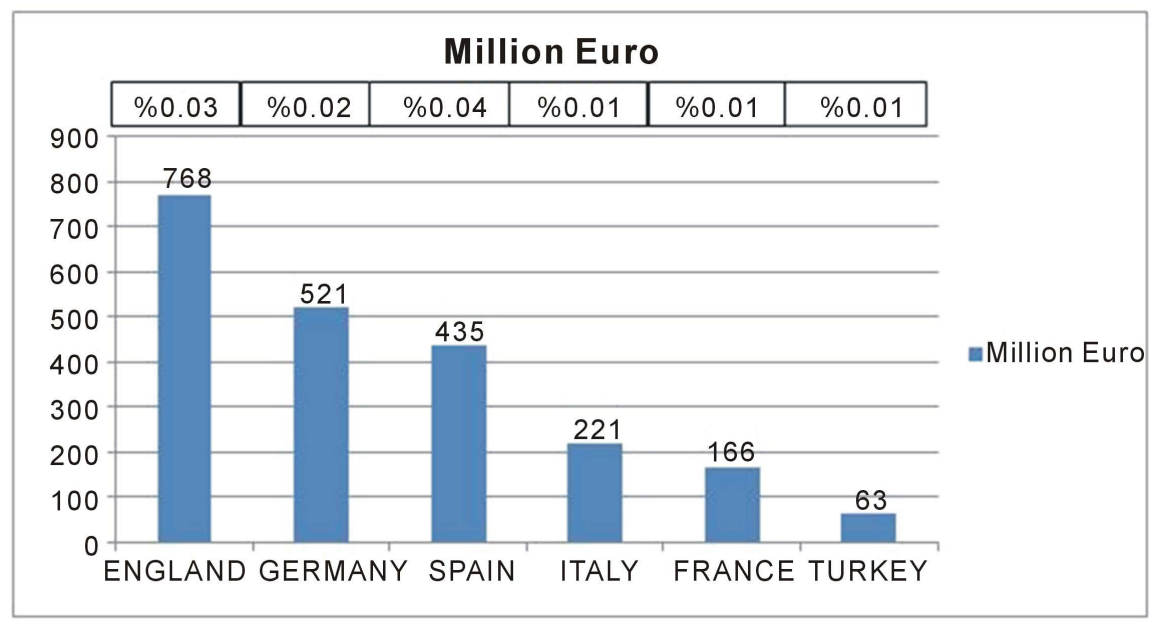

Figure 3. The ratio of the 5 major leagues of Europe and the Spor Toto Super League to the Gross Domestic Product (GDP) ratios of the match day income. Note: The table was created by calculating the average ticket price and an average audience of the super league with Deloitte money league report [7]. 


\section{The Importance of Brand Value in Football Economy}

Television and internet, which act like a distribution channel for industrial football, have also made it possible for football to become widespread, to develop and to reproduce itself. Today, sports clubs and leagues, which show great development in terms of economy, not only succeed in sporting success but also successful management models in terms of financial parameters. This both increases the brand value of both the clubs and the federations of the country, and decreases the brand value of those who cannot succeed.

According to the American Marketing Association; brand; a name, a term, a mark, an icon, a design, or various combinations thereof for identifying, identifying and distinguishing goods or services of one or a group of producers or sellers of goods or services from their competitors [8]. In a sense it is the sum of the values that have been identified with that brand in the past marketing done to the mark. Investors are concerned with brand value in financial terms. So if you want to find a good sponsor both as a club and as a federation, you have to increase brand value.

The brand value offers the advantage of differentiation that allows producers to create higher profit targets. It provides business producers to develop new products, to present them to market and to protect brands from the attacks of competing businesses [10].

When Figure 4 is examined, it is seen that there are four dimensions constituting brand value. These four dimensions constitute the brand value perceived by the consumers, and as a result, perceived brand value values both the costumers and the businesses. This information on brand value is available for all businesses, as well as economic parameters which are increasing day by day in the soccer economy [9].

In this context, according to Brand Finance Reports in 2016 England, Spain, Germany, France, Italy League and football brands which competing in this league are leading global football industry. The football economy has reached a

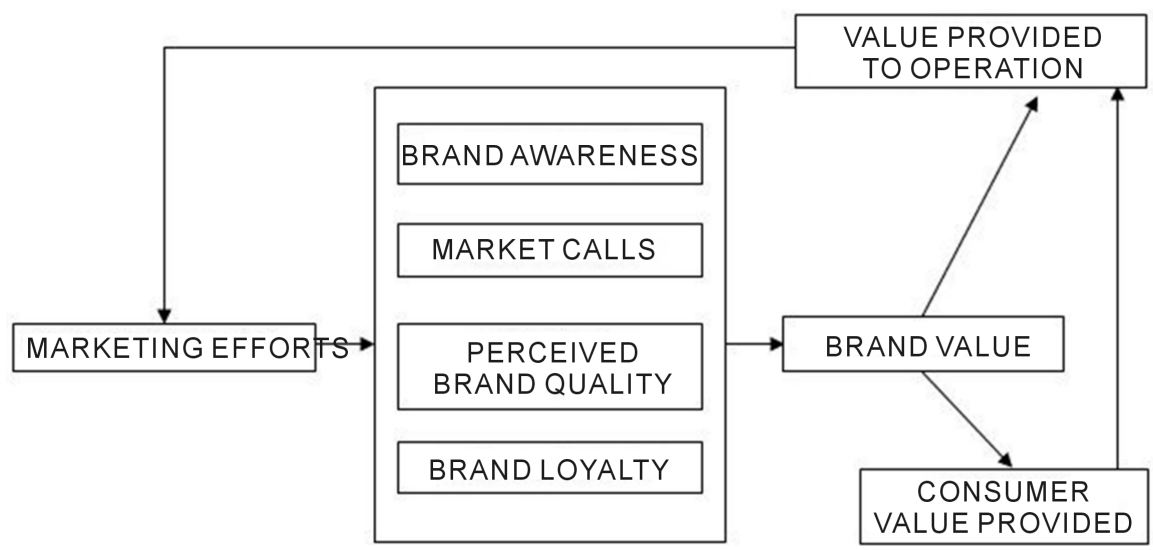

Figure 4. Conceptual structure of consumer based brand value. Source: Avcilar, M.Y. (2008). Measurement of consumer based brand value, Çukurova University Journal of Social Sciences Institute, p. 13. 
brand value created by these 50 football clubs and totaling $\$ 15.02$ billion [11].

Chart 1 shows the countries that share the brand name according to their brand value in June 2016.

Chart 1 shows that UK has the greatest brand value with $48 \%$, followed by Spain with $19 \%$, Germany with $16 \%$, France with $8 \%$ and Italy with $6 \%$, and Turkey, Netherlands and Portugal have the lowest brand value with 1\% [11].

Chart 2 shows countries brand value conducted by Brand Finance June 2017. Manchester United is the most valuable club in the World with a brand value of 1 billion 773 million dollars. While Galatasaray was ranked 39th with a brand value of 116 million dollars from Turkey in 2016, Fenerbahçe was ranked 45th with its brand value of 95 million dollars. According to Brand Finance Report 2017 Galatasaray which had 100 million dollars of the brand value and Fenerbahçe which had 123 million dollars of the brand value weren't among the top 50 clubs [12].

In the Premier League, the team with the highest commercial revenues is Manchester United. According to the March 2016 financial indicators, only in

\title{
Countries by Brand Value (\%)
}

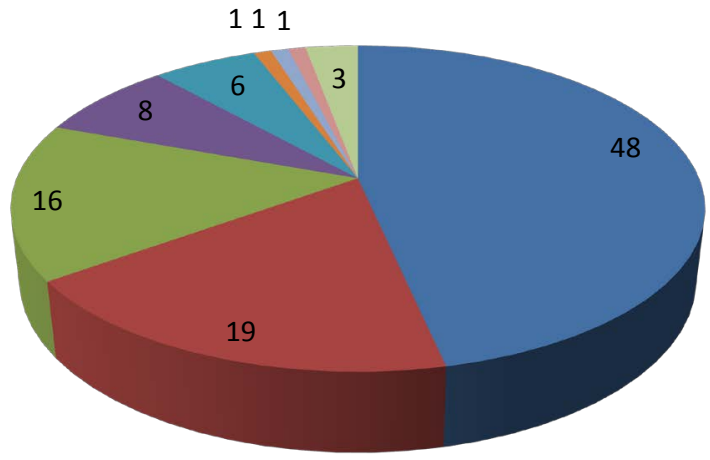

$\square$ ENGLAND
SPAIN
GERMANY
$\square$ FRANCE
$\square$ ITALY
NETHERLANDS
$\square$ TURKEY
PORTUGAL
OTHERS

Chart 1. June 2016 countries by brand value (\%). Source: Brand Finance Football 50 Reports, 2016.

\section{Countries by Brand Value (\%)}

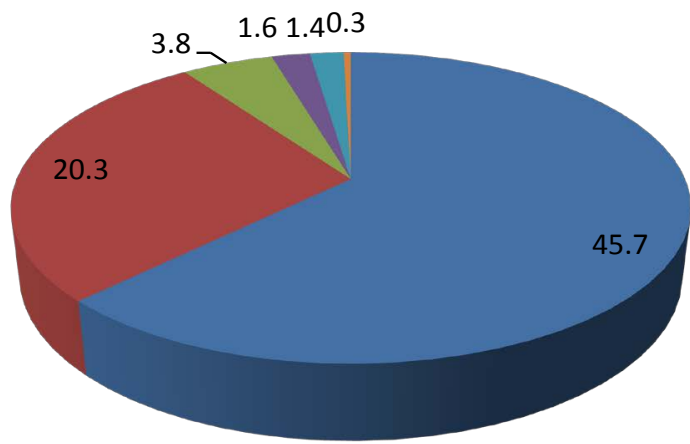

\author{
ENGLAND \\ - GERMANY \\ SPAIN \\ - FRANCE \\ - ITALY \\ - OTHERS
}

Chart 2. June 2017 countries by brand value (\%). Source: Brand Finance Football 50 Reports, 2017. 
the first quarter of 2016, the club increased its commercial income by $37.7 \%$ and earned $£ 65.8$ million. Included in other income, the revenue expected to enter the red-whites by the end of the year is around 500 million pounds. Manchester United-Adidas partnership is at the top of the sponsorship agreements sponsored by sports brands with football clubs. Adidas will pay 75 million pounds each season for the contract that will go on until 2025. The second place is Bayern Munich-Adidas partnership with 60 million Euros. Puma is third in the list with a $£ 30$ million annual sponsorship fee for Arsenal for five seasons.

One of the most popular sponsors stands out as the stadium name sponsor. It is the first example in this area that Bolton Wanderes from Premier League teams changed their stadium name to Reebook Stadium in 1997. North London team Arsenal changed its name to Emirates Stadium which name is Ashburton Grove, in 2004 under the agreement with a UAE based company Emirates. Arsenal will win $£ 30$ million each season from the name sponsorship of this form and stadium which was renewed in 2012 and will run until 2028. Another Premier League team, Manchester City, has won a stadium title and a chest sponsor for $\$ 40$ million a year in line with an agreement with Etihad which the second largest airline in the United Arab Emirates [6].

The identification of stadium names with brands is also a common tradition in the Bundesliga. The 35-year deal Bayern Munich signed with Allianz is at the top of the Bundesliga's most revenue-generating partnerships. The club will earn a minimum of 210 million Euros during the deal. Schalke 04 earned 5.5 million Euros per season in second place and Borussia Dortmund with 4.7 million Euros in third place.

As you can see, leagues need to reach a certain brand value in order to get a good place in the football economy and to achieve success in both clubs and national teams. Administrative work to be done for this purpose is gathered in two groups. These studies should be made by the joint efforts of the football federation and its affiliated leagues and the clubs operating in these leagues (Figure 5). These:

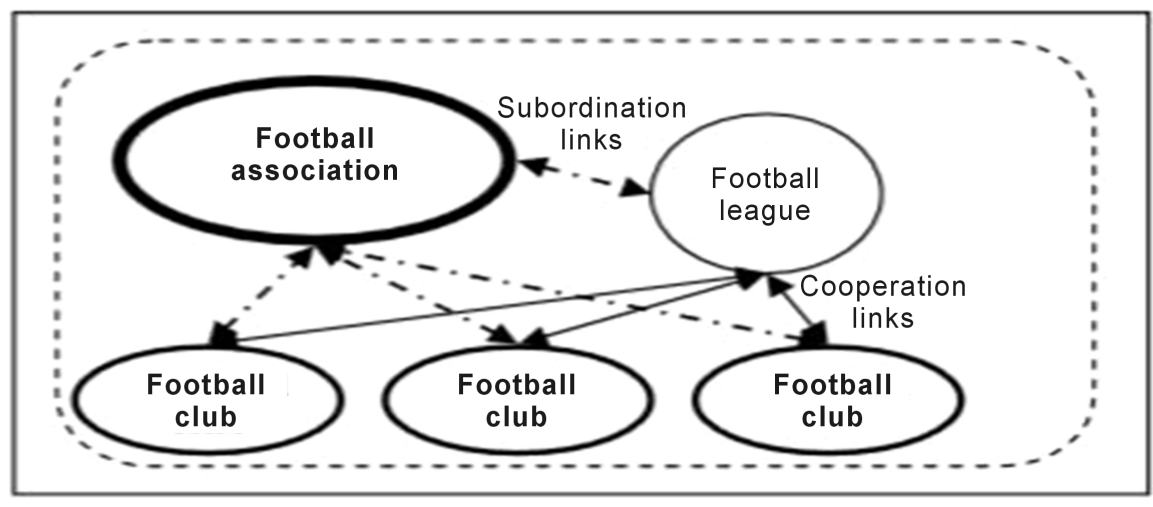

Figure 5. The structure of football business medium. Source: Karpavicius and Jucevicius (2009), "The application of the business system concept to the analysis of football business”, Inzinerine Ekonomika-Engineering Economics, p. 89. 
- Services that guarantee football match performance. So the factors are necessary for sporting success.

- Football business management activities required for the functioning of the whole football business system. So commercial and financial development efforts.

\section{Turkish Football Federation}

On April 13, 1923, in other words when the Republic was not declared yet, "Turkey Football Federation" was formed within the structure of the Alliance of Turkish Civics in Turkey. Football Federation was accepted to FIFA membership on May 21, 1923 and established Turkish National Soccer Team. UEFA membership took place in 1962. On July 3, 1992, it had a fully autonomous structure. It is the soccer federation that has the legal and managerial power to manage, supervise, organize and regulate the football in our country.

Turkey Football Federation has the power of football. It is a legal structure that governs a size reaching $602,193,088 \mathrm{TL}$ in our country. When we examine the income-outgoings situation and financial structure of the federation.

\subsection{Turkish Football Federation's Professional Football Incomes (TL)}

The budget realized as 51,995,577 TL in the 2003-2004 season, 240 million TL in the 2012-2013 season. Table 1 shows Turkish Football Federation's Professional Football Incomes in season 2016-2017. The budget was realized as 500 million TL in the 2016-2017 season. In the 2017-2018 season, a budget of 669 million TL is planned. The budget estimated at $602,193,088$ in 2016-2017 season seems to have remained at 500 million TL due to erroneous planning as it was going to play final in EURO 2016 championship [13].

Table 1. Season 2016-2017 Turkish Football Federation's professional football incomes (TL).

\begin{tabular}{cccc}
\hline INCOMES & $2016 / 2017(\mathrm{TL})$ & Happening & 2017/2018 (TL) \\
\hline Education Incomes & $7,348,560$ & 515,59 & $6,657,670$ \\
National Team Incomes & $141,176,076$ & $55,508,888$ & $40,453,930$ \\
Professional Football Incomes & $259,084,778$ & $270,688,580$ & $348,887,741$ \\
Amateur Football Incomes & $19,501,625$ & $20,384,454$ & $54,234,780$ \\
UEFA and FIFA Incomes & $21,512,750$ & $18,548,159$ & $11,400,000$ \\
Sponsorship Incomes & $106,457,532$ & $56,978,016$ & $124,077,201$ \\
Current Incomes & $8,800,000$ & $6,783,320$ & $12,600,000$ \\
Prior Period Incomes Surplus & $38,311,767$ & $70,911,678$ & $70,911,678$ \\
Total & $\mathbf{6 0 2 , 1 9 3 , 0 8 8}$ & $\mathbf{5 0 0 , 3 1 8 , 6 8 5}$ & $\mathbf{6 6 9 , 2 2 3 , 0 0 0}$ \\
\hline
\end{tabular}

*TL: Turkish Liras. Note: Data was taken from Turkey Football Federation Ordinary General Assembly 2016-2017 Activity Report. 
As a result, unearned revenues and unnecessary expenses have the same effect on revenues and expenditures in the budget. When we look at the table, there is a big drop in the income of the National Team. Both the financial and sporting failures seen in sports clubs are often seen in the Turkish Football Federation.

\subsection{Turkish Football Federation's Professional Football Outgoings (YTL)}

Table 2 shows Turkish Football Federation's Professional Football Outgoings in season 2016-2017. When the expenditure distribution is examined on the basis of federation, it is observed that the highest outgoings are in the professional team with $157,116,944 \mathrm{TL}$ and the second highest outgoings is in the national team with $115,595,158$ TL. On the estimated budget of $2017 / 2018$, the same expenses are planned in high level and it is expected that the total cost of both expenditures will be realized as 474,082,936 TL [13].

When we look at the income-outgoings balance between the years 2016-2017 of the Federation, it is observed that 54 million TL savings achieved. As long as financial budget and budget discipline cannot be achieved, brand values of leagues start to fall day by day. Pool incomes distributed according to the criteria for inclusion among the first 6 teams, live broadcast incomes, performance bonus, championship bonus reached to 871 million TL in the 2015-2016 football season.

Table 2. Season 2016-2017 Turkish Football Federation's professional football outgoings (TL).

\begin{tabular}{|c|c|c|c|}
\hline OUTGOINGS & $2016 / 2017(\mathrm{TL})$ & Happening & $2017 / 2018(\mathrm{TL})$ \\
\hline Education Outgoings & $19,408,827$ & $16,825,749$ & $19,975,086$ \\
\hline National Team Outgoings & $223,025,803$ & $115,595,158$ & $74,762,562$ \\
\hline $\begin{array}{c}\text { Professional Football } \\
\text { Outgoings }\end{array}$ & $148,986,363$ & $157,116,944$ & $399,320,374$ \\
\hline $\begin{array}{l}\text { Amateur Football } \\
\text { Outgoings }\end{array}$ & $46,666,352$ & $51,257,633$ & $54,431,780$ \\
\hline $\begin{array}{c}\text { Disabled Football and } \\
\text { Educational Institution } \\
\text { Outgoings }\end{array}$ & $1,973,218$ & $1,996,965$ & $2,063,630$ \\
\hline $\begin{array}{l}\mathrm{R} \& \mathrm{D} \text { and Project Out- } \\
\text { goings }\end{array}$ & $18,257,458$ & $14,930,494$ & $15,140,400$ \\
\hline Current Incomes & $55,123,757$ & $57,048,731$ & $59,870,984$ \\
\hline Fund Incomes & 100 & 43 & 100 \\
\hline Fixed Assets & $54,405,300$ & $14,596,960$ & $81,141,250$ \\
\hline Statutory Outgoings & $20,670,917$ & $17,060,352$ & $21,551,800$ \\
\hline TOTAL & $588,617,995$ & $446,471,986$ & $728,357,866$ \\
\hline
\end{tabular}

*TL: Turkish Liras. Note: Data was taken from Turkey Football Federation Ordinary General Assembly 2016-2017 Activity Report. 
According to the league values calculated on the basis of the league's betting prices as of season 2016-2107, Super League is the most valuable seventh league of Europe with a value reaching 843 million Euros. Despite such economic and managerial difficulties, it is expected that there will be a financial decline in the 2016-2017 season, especially due to the Financial Fair Play applications, resulting in the Super League teams getting out of the hands of costly players. To explain briefly the applications of the Financial Fair Play; the amount of salary, wages and premium paid to the athletes does not exceed seventy percent of the collected income.

Football Federation is the most important of the main actors of football. Although it has provided a certain revenue increase, it has not been able to maintain and develop itself, its clubs and hence its leagues in a managerial sense. With increasing administrative difficulties in the clubs Turkish football has begun to crisscross.

Digiturk has received the auction which will be granted the broadcasting rights for the next five years for Super League and TFF League 1 with a bid of $\$ 500$ million + VAT annually.

In Turkey, live stream revenues are distributed to the Sports Toto Super League teams as follows: $35 \%$ of the total broadcast revenue is distributed equally to 18 clubs as a contribution. $45 \%$ of the remaining revenues are awarded to performance (score points), $11 \%$ to the championship numbers and $9 \%$ to the first six teams.

Table 3 shows Super League Revenue Distribution Pool. As the Turkish football

Table 3. Super league revenue distribution pool (TL).

\begin{tabular}{|c|c|c|c|c|c|}
\hline & \multicolumn{5}{|c|}{ Super League Revenue Distribution Pool (TL) } \\
\hline & $2016-2017$ & 2015-2016 & $\begin{array}{c}\text { Increase } \\
(\%)\end{array}$ & $\begin{array}{l}\text { Share } \\
(\%)\end{array}$ & Prize \\
\hline Win & $1,500,000$ & $1,300,000$ & 15.38 & & \\
\hline Draw & 750,000 & 650,000 & 15.38 & 46 & Sporty Performance \\
\hline Champion Bonus & $19,000,000$ & $17,000,000$ & 11.76 & & \\
\hline 2nd Place Bonus & $15,500,000$ & $14,000,000$ & 10.71 & & \\
\hline 3rd Place Bonus & $11,500,000$ & $10,000,000$ & 15.00 & & \\
\hline 4th Place Bonus & $7,700,000$ & $7,000,000$ & 10.00 & 6 & Ranking Bonus \\
\hline 5th Place Bonus & $3,850,000$ & $3,500,000$ & 10.00 & & \\
\hline 6th Place Bonus & $1,925,000$ & $1,750,000$ & 10.00 & & \\
\hline $\begin{array}{c}\text { Former Champion } \\
\text { Bonus }\end{array}$ & $1,800,000$ & $1,600,000$ & 12.50 & 12 & Old Championship \\
\hline $\begin{array}{c}\text { Evenly Distributed } \\
\text { Amount }\end{array}$ & $20,000,000$ & $18,000,000$ & 11.11 & 36 & $\begin{array}{c}\text { Evenly Distributed } \\
\text { Amount }\end{array}$ \\
\hline $\begin{array}{c}\text { Total Amount } \\
\text { Distributed }\end{array}$ & $988,275,000$ & $871,050,000$ & 13.46 & 100 & $\begin{array}{c}\text { Total Amount } \\
\text { Distributed }\end{array}$ \\
\hline
\end{tabular}

Source: Akşar, T. (2017) [16]. 
economy grew, pool revenues also increased in the Super League. As a matter of fact, considering the distribution of the last 3 years between 2014-2017 seasons, the total monetary award distributed to the clubs increased by $31 \%$ and reached 988,275,000 TL. The average amount of Super League 2016-17 pool revenues distributed per team also rose to 54.9 million TL from 41.8 million TL in this period [14] [15] [16].

In today's football, two important structures emerge in the process of restructuring for federations and clubs. These:

- Asset-Risk Management

- Sporty Performance Management

These two structures must be planned by the Turkish Football Federation and the clubs and reach the point where Turkish Football is worthy.

\section{Conclusions}

Football is the most popular sport in the world, both in national and international level. Today, when it is considered that there are many countries called to mind with football, football with this popularity plays an important role to advertise many countries. Participation in international football tournaments which are watched by a large number of people is of great importance in this sense. But more important than that is that such international tournaments/organizations can be realized within the country. Because, nowadays, the regulation of such big sports tournaments/organizations can make big contributions to the economy rather than being considered as a cost element for the countries. Sport was limited to services produced in small and non-profit enterprises. This structure was not suitable for the interest of the economy.

Especially in terms of sporty performance, the difference between us and our competitors is getting bigger every day. Neither the individual sports nor the expected success in team sports can be achieved. Unfortunately, the clubs that did not meet their income expenses suffered financial hardship and were penalized for deleting points.

The task of developing football in Turkey and preparing new legal regulations has been given to Turkish Football Federation. It is necessary to regulate professional football, to establish a regulatory and legal framework, to ensure that the clubs have a transparent management structure and to support the clubs and bring the football economy to European standards. Like any business, soccer organizations also need a strong financial management system to ensure long-term sustainability.

The necessity of restructuring has arisen from the point of view that the high-budget football clubs that come out as a supplier in the soccer industry which has become a big business line with globalization can adapt to the changing economic conditions and take advantage of the opportunities brought about by these conditions. Nowadays, the presence of transparent and sound financial structure is important on the basis of accountability in football clubs which are 
attracting attention due to the size of funds they manage and their public offering attempts.

The present administrative and organizational structure of Turkish sport is not structured to carry sportive, economic, financial and intellectual performance to the highest level. With today's structuring, Turkish sports seem far away from the competence to increase their share in sport and finances in Europe and the World. For this reason, new projects have to be produced and passed on to a new life.

\section{References}

[1] http://nfltr.com/2015

[2] Güngör, A. (2014) Analysis of Relation between Sportive Success and Financial Performance in Football Industry and Turkey's Application. Istanbul University Journal of Social Sciences, No. 1, 16-36.

[3] Akşar, T. (2010) Politics of Football Economy. Literature Publications, İstanbul, 3.

[4] Karpavicius, T. and Jucevicius, G. (2009) The Application of the Business System Concept to the Analysis of Football Business. Inzinerine Ekonomika-Engineering Economics, 87.

[5] Skorer (2017). http://www.milliyet.com.tr/4-buyuklerin-borcu-6-5-milyar-besiktas-galatasaray-fen erbahce-trabzonspor-2456218-skorerhaber/

[6] Ekolig Reports 2015-2106.

[7] Deloitte Money League 2016.

[8] Kotler, P. (2000) Marketing Management. 9th Edition, Prentice Hall, International Inc., Boston.

[9] Avcilar, M.Y. (2008) Measurement of Consumer Based Brand Value. Çukurova University Journal of Social Sciences Institute, 17, 11-30.

[10] Lassar, W., Banwari, M. and Arun, S. (1995) Measuring Customer-Based Brand Eguity. Journal of Marketing, 12, 11-19.

[11] Brand Finance (2016) Brand Finance Football 502016. http://brandfinance.com/knowledge-centre/reports/brand-finance-football-50-2016/

[12] Brand Finance (2017) Brand Finance Football 502017. http://brandfinance.com/knowledge-centre/reports/brand-finance-football-50-2017/

[13] Turkish Football Federation (2017) Turkish Football Federation Ordinary General Assembly 2016-17 Annual Report.

[14] Akşar, T. (2017) Super League Super? http://www.futbolekonomi.com/index.php/haberler-makaleler/ekonomi/35-tugrula ksar/4210-2017-10-03-08-08-24.html

[15] Akşar, T. (2017) Unbalanced Economic Competition in Super League! http://www.futbolekonomi.com/index.php/haberler-makaleler/ekonomi/35-tugrula ksar/4167-2017-07-16-16-58-48.html

[16] Akşar, T. (2017) Super League Has Distributed Fortune! http://t24.com.tr/yazarlar/tugrul-aksar/super-lig-servet-dagitti,17414 